\title{
RESEARCH PAPER \\ In vitro and glasshouse biocontrol of Rhizoctonia solani with improved strains of Trichoderma spp.
}

\author{
Jaime R. Montealegre ${ }^{1}$, Fabián Ochoa ${ }^{1}$, Ximena Besoain², Rodrigo Herrera $^{1}$, \\ and Luz M. Pérez ${ }^{3}$ \\ ${ }^{1}$ Departamento de Sanidad Vegetal, Facultad de Ciencias Agronómicas, Universidad de Chile. Casilla 1004, \\ Santiago, Chile. \\ ${ }^{2}$ Facultad de Agronomía, Pontificia Universidad Católica de Valparaíso. Casilla 4-D, Quillota, Chile. \\ ${ }^{3}$ Asesorías e Inversiones Biostrategy Ltda., Hernando de Aguirre 1372, Santiago, Chile.
}

\begin{abstract}
J.R. Montealegre, F. Ochoa, X. Besoain, R. Herrera, and L.M. Pérez. 2014. In vitro and glasshouse biocontrol of Rhizoctonia solani with improved strains of Trichoderma spp. Cien. Inv. Agr. 41(2):197-206. The potential of Trichoderma spp. fusants for the biocontrol of Rhizoctonia solani was compared with the ability of their corresponding parental strains. Their effect was tested in vitro using two R. solani strains, 509 (AG 2-1) and 618 (AG 4). The highest inhibitions in growth in dual cultures were obtained with the ThF2-1 (89.79\%), ThF33 (90.55\%), ThF4-15 (91.75\%) and ThF5-8 (77.67\%) fusants on R. solani 509; only ThF2-1 was able to inhibit the growth of $R$. solani $618(60.19 \%)$. The inhibitory effect on growth was mainly due to diffusible metabolites. Percent mortality and canker level in tomato plants were evaluated in glasshouse experiments where all of the evaluated fusants suppressed plant mortality, but only ThF2-1 and ThF5-8 significantly decreased the canker level.
\end{abstract}

Key words: Biological control, methyl bromide, tomato, Solanum lycopersicum.

\section{Introduction}

Tomato (Solanum lycopersicum Mill.) fruit production under greenhouse conditions can be reduced by several pathogens, which thrive due to monoculture conditions that concentrate microorganisms, such as Rhizoctonia solani, in the soil (Latorre, 2004). R. solani attacks different crops, but only isolates belonging to $\mathrm{AG} 4$ and AG-2-1 anastomosis groups have been found

Received April 8, 2014. Accepted July 2, 2014. Corresponding author: jmonteal@uchile.cl to attack tomatoes in Chile (Montealegre et al., 2003). The control of this pathogen still depends on methyl bromide (MeBr).

Research on alternatives to the use of agrochemicals has increased not only because of their beneficial effects for the environment but also due to global regulations and consumer demand. Biocontrol microorganisms (BCM), either wild or improved, have arisen as alternatives for the control of phytopathogens. Protoplast fusion of wild Trichoderma strains has allowed for new strains to be obtained (Stasz et al., 1988) that show increased antagonistic effects (Ogawa et 
al., 2000), faster growth and abundant sporulation (Prabavathy et al., 2006). Specifically, antagonistic activity against Pyrenochaeta lycopersici has increased (Besoain et al., 2007), and it is important to know whether the improved strains could be used for the biocontrol of other phytopathogens.

Taking into account that $R$. solani is responsible for losses of tomato crops in Chile and considering the availability of new Trichoderma strains obtained by protoplast fusion (Besoain et al., 2007), it is important to test whether the biocontrol activity of these strains against this phytopathogen is improved compared to their corresponding parental strains. This work describes the biocontrol activity, both in vitro and in glasshouse conditions, of several Trichoderma fusant strains against the two anastomosis groups of $R$. solani that infect tomato crops in Chile.

\section{Materials and methods}

\section{Fungal strains}

R. solani strains 509 (AG 2-1) and 618 (AG 4), both of which were isolated from tomato crops in Chile and are sensitive to pencycuron, were obtained from the laboratory collection. Additionally, the following T. harzianum fusants obtained by protoplast fusion (Besoain et al., 2007) were used for the in vitro tests: ThF2 Series (ThVxTh291): ThF2-1,ThF2-10, ThF212, ThF2-18; ThF3 Series (ThVxTh11): ThF3-2, ThF3-3, ThF3-4, ThF3-6, ThF3-7; ThF4 Series (ThVxTh12): ThF4-13, ThF4-15; ThF5 Series (Th11xTh12): ThF5-8; ThF6 Series (Th12xTh291): ThF6-2. The following T. harzianum fusants were used for in vivo (glasshouse) tests: ThF2 Series: (ThVxTh291): ThF2-1, ThF2-18; ThF3 Series (ThVxTh11): ThF3-3; ThF4 Series (ThVxTh12): ThF4-15; ThF5 Series: ThF5-8 along with the parental T. harzianum strains, ThV, Th291, Th11 and Th12 that were used as controls.

\section{Tomato plants}

Tomato plant cultivars (cvs.) 92.95 and Gondola, which are susceptible to $R$. solani, were used for the glasshouse assays.

In vitro assays for $R$. solani development inhibition

Dual cultures. One disk (5 mm) containing four days culture of $R$. solani 509 or $R$. solani 618 was placed at one side of a Petri dish containing Potato Dextrose Agar (PDA - Difco), and one disk (5 $\mathrm{mm}$ ) with four days culture of one of the fusant Trichoderma strains was placed at the other side of the plate and in front of the phytopathogen (Dennis and Webster, 1971a). Plates were prepared under the optimal $\mathrm{pH}$ conditions and then incubated at the optimal temperatures for R. solani 509 ( $\mathrm{pH} 7.0$, $20^{\circ} \mathrm{C}$ ) or $R$. solani $618\left(\mathrm{pH} 6.5,22^{\circ} \mathrm{C}\right)$. Controls were run on PDA plates inoculated with either $R$. solani 509 or $R$. solani 618 and mock-inoculated with a $5 \mathrm{~mm}$ disk of PDA. The growth diameter of the pathogen in the controls was measured with a ruler and compared to its corresponding growth in the presence of the fusant Trichoderma strain over the same time period as the controls. Percent inhibition of radial growth (IRG) was established using the Dennis and Webster formula (1971a): $\operatorname{IRG}(\%)=\left(R_{1}-R_{2}\right) 100 / R_{1}$, where $R_{1}$ is the farthest distance covered by the pathogen in the control plates, and $\mathrm{R}_{2}$ is the distance covered by the fusant towards the antagonist. Each experiment was run in five replicates and repeated twice. The results (as percentages) are presented as the mean for each treatment and were first transformed using the Bliss Angular Transformation before testing with an ANOVA. The Tukey's test was used if significant differences were obtained $(\mathrm{P} \leq 0.05)$.

\section{Effect of volatile metabolites}

A $5 \mathrm{~mm}$ disk of pure culture of $R$. solani 509 or $R$. solani 618 or one of the T. harzianum fusants 
was placed in the middle of a Petri dish containing PDA. One half plate containing one of the T. harzianum fusant strains and another containing one of the $R$. solani strains were placed face to face to avoid any physical contact between the fungi (Dennis and Webster, 1971b). The half plates were sealed to isolate the atmosphere inside and prevent the loss of the volatiles formed. Plates were incubated at the same temperature and $\mathrm{pH}$ conditions as described for the dual cultures above. Controls were run with one half plate containing one of the pathogen strains while the other was mock-inoculated with a 5-mm disk of PDA. The growth diameter of the pathogen in the control treatment was measured and compared to those in the presence of the corresponding fusant Trichoderma strain. Percent IRG was established as IRG $(\%)=(1-\mathrm{R} 2 / \mathrm{R} 1) 100$, where R1 is the distance covered by the pathogen in the controls, and $\mathrm{R} 2$ is the distance covered by the pathogen in its half plate in the presence of the antagonist in the other half plate. Each experiment was run in five replicates and was repeated twice. The results (as percentages) are the mean of each treatment and were first transformed using the Bliss Angular Transformation before testing with an ANOVA. The Tukey's test was used if significant differences were obtained $(\mathrm{P} \leq 0.05)$.

\section{Effect of diffusible metabolites}

A $5 \mathrm{~mm}$ disk of each of the antagonistic Trichoderma strains was inoculated in the middle of Petri dishes containing PDA covered with a sterile dialysis membrane (3.0 in. Sigma-Aldrich). After incubation for $72 \mathrm{~h}$ at $28^{\circ} \mathrm{C}$, the membrane with the Trichoderma was removed, and the plate was inoculated in the middle with a 5-mm disk of pure R. solani 509 or $R$. solani 618 culture. Plates were further incubated at the same temperatures and $\mathrm{pH}$ conditions as for the dual cultures. Controls were run with mock-inoculated plates using a 5-mm disk of PDA on the sterile dialysis membrane, and after removing the membrane, the plates were inoculated with one of the $R$. solani strains. The growth diameter of the pathogen in the controls was measured with a ruler and compared to that of the pathogen on the PDA where the corresponding fusant Trichoderma strain was previously cultured after the membrane was removed. Percent IRG was established as IRG $(\%)=(1-\mathrm{R} 2 / \mathrm{R} 1) 100$, where $\mathrm{R} 1$ is the distance covered by the pathogen in the controls, and R2 is the distance covered by the pathogen in the plates where the antagonist was previously cultured. Each experiment was run in five replicates and was repeated twice. The results (as percentages) are the mean of each treatment and were first transformed using the Bliss Angular Transformation before testing with an ANOVA. The Tukey's test was used if significant differences were obtained $(\mathrm{P} \leq 0.05)$.

In vivo effect of biocontrol strains on the development of crown and root canker caused by R. solani

The in vivo experiments considered five $T$. harzianum strains that were selected based on the results obtained in in vitro conditions. Their innocuousness on tomato plants cvs. 92.95 and Gondola was previously checked (Besoain et al., 2007) to test their effectiveness for the biocontrol of tomato crown canker caused by $R$. solani 618 (AG 4). The selection of this pathogen strain was based on its aggressiveness, pathogenicity and ability to infect different crops (Anderson, 1982; Sneh et al., 1991).

Glasshouse assays were run using Trichoderma strains contained in alginate pellets (Montealegre and Larenas, 1995). The parental strains (ThV, Th291, Th11, and Th12) were used for comparison. Once fungal innocuousness was established, tomato seedlings of cvs. 92.95 and Gondola were transplanted to $2.3 \mathrm{~L}$ pots containing sterile soil inoculated with $R$. solani 618 (21.0 g inoculum/pot; $8.0 \times 10^{5}$ colony forming units (cfu) $\mathrm{g}^{-1}$ inoculum) grown on sterile oat seeds (Santander et al., 2003). The inoculum was introduced close to where the root pan and the crown of the plant were to be 
placed. The concentration of the inoculum was established after grounding the oat seeds and further serial dilutions in selective culture medium. All of the experiments used $1.7 \mathrm{~g}$ pellets/plant $\left[1.75 \times 10^{5}-8.7 \times 10^{5} \mathrm{cfu} \mathrm{g}^{-1}\right.$ pellet $]$ of the different Trichoderma strains that were placed inside the hole before transplantation. Each treatment had five replicates and was repeated five times. Controls were considered to be the inoculated soil a) in the absence of any Trichoderma strain and commercial fungicide and $b$ ) in the presence of $0.15 \mathrm{~mL} \mathrm{pot}^{-1}$ of commercial fungicide, pencycuron (liquid suspension, $250 \mathrm{~g}$ active compound $\mathrm{L}^{-1}$ ). Each pot contained one tomato plant of cv. 92.95 or cv. Gondola. Plants were randomly arranged and maintained under glasshouse conditions until flowering. They were then analyzed for crown canker levels as in Montealegre et al. (2010) and for $\%$ mortality of the tomato plants induced by R. solani. The results were analyzed by ANOVA ( $95 \%$ confidence) followed by the Tukey's test if significant differences were detected. Canker levels were analyzed by the Kruskal and Wallis non-parametric test and the Mann-Whitney test for comparing pairs ( $95 \%$ confidence).

\section{Results}

In vitro assays for $R$. solani development inhibition

Dual cultures. The percent inhibition of $R$. solani strains 509 and 618 in dual cultures by the Trichoderma strains resulting from different protoplast fusions is shown in Table 1.

Fusant strains from the ThF2 series (ThVxTh291) showed improved ability to inhibit $R$. solani 509 (ThF2-1, ThF2-10 and ThF2-18) or R. solani 618 (ThF2-1 and ThF2-18) growth in relation to one of their parental strains. ThF2-1 and ThF2-18 were those that were significantly improved in their biocontrol of $R$. solani 509 over ThV as was the biocontrol activity of Th291 for $R$. solani 618 .

Replacing Th291 in the protoplast fusion of (ThVxTh291) with Th11 or Th12 to obtain series ThF3 (ThVxTh11) and ThF4 (ThVxTh12) fusants resulted in the ThF3-3, ThF3-2 and ThF4-15 strains, which were better inhibitors than both

Table 1. Inhibitory effect of the ThF2, ThF3, ThF4, ThF5 and ThF6 series of Trichoderma strains from protoplast fusion on $R$. solani 509 (AG 2-1) and $R$. solani 618 (AG 4) in dual cultures.

\begin{tabular}{|c|c|c|c|c|c|}
\hline \multirow[b]{2}{*}{$\begin{array}{l}\text { A. Strains from series } \\
\text { ThF2 ThV x Th291 }\end{array}$} & \multicolumn{2}{|c|}{$\%$ Growth inhibition } & \multirow[b]{2}{*}{$\begin{array}{l}\text { B. Strains from series } \\
\text { ThF3 ThV x Th11 }\end{array}$} & \multicolumn{2}{|c|}{$\%$ Growth inhibition } \\
\hline & $\begin{array}{l}\text { R. solani } 509 \\
(\mathrm{AG} 2-1)\end{array}$ & $\begin{array}{l}\text { R. solani } 618 \\
(\mathrm{AG} 4)\end{array}$ & & $\begin{array}{l}\text { R. solani } 509 \\
(\mathrm{AG} 2-1)\end{array}$ & $\begin{array}{c}\text { R. solani } 618 \\
\text { (AG 4) }\end{array}$ \\
\hline ThF2-1 & $89.79 \mathrm{a}$ & $60.19 \mathrm{a}$ & ThF3-3 & $90.55 \mathrm{a}$ & $55.81 \mathrm{a}$ \\
\hline ThF2-10 & $89.02 \mathrm{a}$ & $53.46 \mathrm{ab}$ & ThF3-2 & $86.61 \mathrm{a}$ & $51.42 \mathrm{a}$ \\
\hline ThF2-18 & $84.50 \mathrm{ab}$ & $54.68 \mathrm{a}$ & ThF3-4 & $74.79 \mathrm{ab}$ & $49.16 \mathrm{a}$ \\
\hline T. $h 291^{1}$ & $82.96 \mathrm{a}$ & $44.69 \mathrm{~b}$ & ThF3-6 & $69.13 \mathrm{ab}$ & $50.43 \mathrm{a}$ \\
\hline ThF2-12 & $53.77 \mathrm{bc}$ & $54.02 \mathrm{ab}$ & ThF3-7 & $68.39 \mathrm{ab}$ & $52.58 \mathrm{a}$ \\
\hline T. $h \mathrm{~V}^{1}$ & $47.47 \mathrm{c}$ & $53.98 \mathrm{ab}$ & T. $h \mathrm{~V}^{1}$ & $47.47 \mathrm{~b}$ & $53.98 \mathrm{a}$ \\
\hline & & & T. $h 11^{1}$ & $47.41 \mathrm{~b}$ & $55.09 \mathrm{a}$ \\
\hline $\begin{array}{l}\text { C. Strains from series } \\
\text { ThF4 ThV x Th12 }\end{array}$ & $\begin{array}{l}\text { R. solani } 509 \\
(\mathrm{AG} 2-1)\end{array}$ & $\begin{array}{l}\text { R. solani } 618 \\
(\mathrm{AG} 4)\end{array}$ & $\begin{array}{c}\text { D. Strains from series } \\
\text { ThF5 Th11 x Th12 }\end{array}$ & $\begin{array}{l}\text { R. solani } 509 \\
(\mathrm{AG} 2-1)\end{array}$ & $\begin{array}{c}\text { R. solani } 618 \\
(\mathrm{AG} 4)\end{array}$ \\
\hline ThF4-15 & $91.75 \mathrm{a}$ & $49.90 \mathrm{a}$ & ThF5-8 & $77.67 \mathrm{a}$ & $44.46 \mathrm{~b}$ \\
\hline T. $h 12^{1}$ & $49.05 \mathrm{~b}$ & $53.42 \mathrm{a}$ & T. $h 12^{1}$ & $49.05 \mathrm{~b}$ & $53.42 \mathrm{a}$ \\
\hline ThF4-13 & $48.98 \mathrm{~b}$ & $30.62 \mathrm{~b}$ & T. $h 11^{1}$ & $47.41 \mathrm{~b}$ & $55.09 \mathrm{a}$ \\
\hline T. $h \mathrm{~V}^{1}$ & $47.47 \mathrm{~b}$ & $53.98 \mathrm{a}$ & & & \\
\hline $\begin{array}{l}\text { E. Strains from series } \\
\text { ThF6 Th12 xTh291 }\end{array}$ & $\begin{array}{l}\text { R. solani } 509 \\
(\mathrm{AG} 2-1)\end{array}$ & $\begin{array}{l}\text { R. solani } 618 \\
(\mathrm{AG} 4)\end{array}$ & & & \\
\hline T. $h 291^{1}$ & $44.39 \mathrm{a}$ & $13.17 \mathrm{a}$ & & & \\
\hline ThF6-2 & $28.29 \mathrm{~b}$ & $2.44 \mathrm{~b}$ & & & \\
\hline T. $h 12^{1}$ & $27.80 \mathrm{~b}$ & $8.78 \mathrm{a}$ & & & \\
\hline
\end{tabular}

${ }^{1}$ Parental strain. Different letters in columns indicate significant differences after Tukey's test at $\mathrm{P} \leq 0.05$. 
parental strains but only towards $R$. solani 509 . In contrast, the replacement of ThV with Th12 in the protoplast fusion of ( $\mathrm{ThVxTh291)}$ resulted in ThF6-2 (Th12xTh291), which showed a decreased ability to control $R$. solani 509 or $R$. solani 618 when compared to Th291 or both parental strains, respectively. Finally, the inhibitory activity of ThF5-8 (Th11xTh12) towards $R$. solani 509 was significantly improved, but it decreased toward R. solani 618 .

\section{Volatile metabolites}

The percent inhibition of $R$. solani 509 and $R$. solani 618 by the volatile metabolites secreted by the different Trichoderma strains resulting from protoplast fusion is shown in Table 2. In general, no improvement was observed in the inhibitory effect of volatiles on $R$. solani 509 or $R$. solani 618 in the cultures with the exception of ThF2-12 on $R$. solani 509 when compared to the parental strain ThV. In addition, most of these strains showed no inhibitory effect on $R$. solani 618 (Table 2).

\section{Diffusible metabolites}

The inhibition of $R$. solani 509 and $R$. solani 618 growth by diffusible metabolites secreted by the different Trichoderma strains resulting from protoplast fusion was higher than $80 \%$ for most of the strains, as shown in Table 3. In general, the improvement of the inhibitory effect of the different Trichoderma strains on $R$. solani 509 and $R$. solani 618 was due to one of the parental strains with the exception of three strains from the ThF2 series, ThF2-1, ThF2-12 and ThF2-18 (Table 3), whose results were better than both parents for the control of $R$. solani 509 .

In vivo effect of biocontrol strains on the development of crown and root canker caused by R. solani

The fusants with the best biocontrol activity against $R$. solani 509 and/or 618 in the diffusible metabolite assays, ThF2-1, ThF2-18, ThF3-3, ThF4-15 and ThF5-8 (Table 3), were innocuous to tomato plant cvs. 92.95 and Gondola (data not shown) and were used in these trials.

Table 2. Inhibitory effect of the volatiles secreted by the ThF2, and ThF3, ThF4, ThF5, and ThF6 series of the Trichoderma strains from protoplast fusion on $R$. solani 509 (AG 2-1) and on R. solani 618 (AG 4).

\begin{tabular}{|c|c|c|c|c|c|}
\hline \multirow[b]{2}{*}{$\begin{array}{l}\text { A. Strains from series } \\
\text { ThF2 ThV x Th291 }\end{array}$} & \multicolumn{2}{|c|}{$\%$ Growth inhibition } & \multirow[b]{2}{*}{$\begin{array}{l}\text { B. Strains from series } \\
\text { ThF3 ThV x Th11 }\end{array}$} & \multicolumn{2}{|c|}{$\%$ Growth inhibition } \\
\hline & $\begin{array}{l}\text { R. solani } 509 \\
\text { (AG 2-1) }\end{array}$ & $\begin{array}{c}\text { R. solani } 618 \\
(\mathrm{AG} 4)\end{array}$ & & $\begin{array}{l}\text { R. solani } 509 \\
\text { (AG 2-1) }\end{array}$ & $\begin{array}{c}\text { R. solani } 618 \\
(\mathrm{AG} 4)\end{array}$ \\
\hline ThF2-12 & $31.88 \mathrm{a}$ & $14.15 \mathrm{a}$ & ThF3-2 & $37.00 \mathrm{a}$ & $1.46 \mathrm{~b}$ \\
\hline T. $h 291^{1}$ & $28.75 \mathrm{a}$ & $13.17 \mathrm{a}$ & ThF3-6 & $30.24 \mathrm{a}$ & $0.00 \mathrm{~b}$ \\
\hline ThF2-10 & $16.88 \mathrm{ab}$ & $0.00 \mathrm{~b}$ & ThF3-3 & $29.76 \mathrm{a}$ & $0.00 \mathrm{~b}$ \\
\hline ThF2-1 & $16.25 \mathrm{ab}$ & $0.00 \mathrm{~b}$ & ThF3-7 & $27.81 \mathrm{a}$ & $0.00 \mathrm{~b}$ \\
\hline ThF2-18 & $8.13 \mathrm{~b}$ & $0.00 \mathrm{~b}$ & T. $h \mathrm{~V}^{1}$ & $26.83 \mathrm{a}$ & $7.32 \mathrm{a}$ \\
\hline T. $h \mathrm{~V}^{1}$ & $6.25 \mathrm{~b}$ & $7.32 \mathrm{a}$ & T. $h 11^{1}$ & $26.34 \mathrm{a}$ & $1.95 \mathrm{~b}$ \\
\hline & & & ThF3-4 & $25.00 \mathrm{a}$ & $0.00 \mathrm{~b}$ \\
\hline $\begin{array}{l}\text { C. Strains from series } \\
\text { ThF4 ThV x Th12 }\end{array}$ & $\begin{array}{l}\text { R. solani } 509 \\
(\mathrm{AG} \mathrm{2-1)}\end{array}$ & $\begin{array}{c}\text { R. solani } 618 \\
(\mathrm{AG} 4)\end{array}$ & $\begin{array}{c}\text { D. Strains from series } \\
\text { ThF5 Th11 x Th12 }\end{array}$ & $\begin{array}{l}\text { R. solani } 509 \\
(\mathrm{AG} 2-1)\end{array}$ & $\begin{array}{c}\text { R. solani } 618 \\
(\mathrm{AG} 4)\end{array}$ \\
\hline ThF4-15 & $28.78 \mathrm{a}$ & $0.00 \mathrm{~b}$ & T. $h 12^{1}$ & $27.80 \mathrm{a}$ & $8.78 \mathrm{a}$ \\
\hline T. $h 12^{1}$ & $27.80 \mathrm{a}$ & $8.78 \mathrm{a}$ & ThF5-8 & $26.83 \mathrm{a}$ & $0.00 \mathrm{c}$ \\
\hline T. $h \mathrm{~V}^{1}$ & $26.83 \mathrm{a}$ & $7.32 \mathrm{a}$ & T. $h 11^{1}$ & $26.34 \mathrm{a}$ & $1.95 \mathrm{~b}$ \\
\hline ThF4-13 & $23.90 \mathrm{a}$ & $2.44 \mathrm{~b}$ & & & \\
\hline $\begin{array}{c}\text { E. Strains from series } \\
\text { ThF6 Th12xTh291 }\end{array}$ & $\begin{array}{l}\text { R. solani } 509 \\
\text { (AG 2-1) }\end{array}$ & $\begin{array}{c}\text { R. solani } 618 \\
(\mathrm{AG} 4)\end{array}$ & & & \\
\hline T. $h 291^{1}$ & $44.39 \mathrm{a}$ & $13.17 \mathrm{a}$ & & & \\
\hline ThF6-2 & $28.29 b$ & $2.44 \mathrm{~b}$ & & & \\
\hline T. $h 12^{1}$ & $27.80 \mathrm{~b}$ & $8.78 \mathrm{a}$ & & & \\
\hline
\end{tabular}

${ }^{1}$ Parental strain. Different letters in columns and rows indicate significant differences after Tukey's test at $\mathrm{P} \leq 0.05$. 
The canker level in control tomato plants inoculated with $R$. solani 618 was higher in cv. 92.95 than in cv. Gondola; no significant decrease in the disease level of any $\mathrm{cv}$. was achieved with the use of the chemical fungicide (Table 4). ThF2-1 and ThF5-8 were the only fusants that significantly reduced the damage produced by $R$. solani 618 in control and pencycuron-treated cv. 92.95 tomato plants, but they showed no significant differences with their corresponding parental strains. However, all fusants showed the ability to suppress plant mortality which differed from their parental strains and the chemical fungicide (Table 4 A). On the other hand, ThF2-18, ThF4-15 and ThF5-8 significantly decreased the level of canker produced by $R$. solani 618 in the control and pencycuron-treated cv. Gondola tomato plants (Table 4B). In addition, all fusants suppressed mortality in this tomato cv. (Table 4B). ThF5-8 was the only fusant that decreased the canker level in both cvs. as its biocontrol activity was not significantly different from its parental strains.

\section{Discussion}

The growth inhibition observed in $R$. solani strains 509 (AG 2-1) and 618 (AG 4) in dual cultures by the wild T. harzianum strains Th291, ThV, Th11 and Th12 (Table 1) is in agreement with the findings of Küçük and Kivanç (2003), and the same result occurred for all the Trichoderma fusants tested. However, only ThF2-1 and ThF2-18 (Th291xThV) showed improved biocontrol activity when compared to one or both parental strains. Thus, the protoplast fusion between Th291 and ThV resulted in two fusant strains with the ability to biocontrol both $R$. solani anastomosis groups in dual cultures. The replacement of Th291 by Th11 or Th12 produced only two and one fusants, respectively, with improved biocontrol activity towards $R$. solani 509 in dual cultures (Table 2, B and C). This suggests that protoplast fusion between $\mathrm{ThV}$ and Th11 or Th12 resulted in the loss of the ability to biocontrol R. solani 618 .

Table 3. Inhibitory effect of the diffusible metabolites secreted by the ThF2, and ThF3, ThF4, ThF5, and ThF6 series of the Trichoderma strains from protoplast fusion on $R$. solani 509 (AG 2-1) and on $R$. solani 618 (AG 4).

\begin{tabular}{|c|c|c|c|c|c|}
\hline \multirow[b]{2}{*}{$\begin{array}{l}\text { A. Strains from series } \\
\text { ThF2 ThV x Th291 }\end{array}$} & \multicolumn{2}{|c|}{$\%$ Growth inhibition } & \multirow[b]{2}{*}{$\begin{array}{l}\text { B. Strains from series } \\
\text { ThF3 ThV x Th11 }\end{array}$} & \multicolumn{2}{|c|}{$\%$ Growth inhibition } \\
\hline & $\begin{array}{l}\text { R. solani } 509 \\
\text { (AG 2-1) }\end{array}$ & $\begin{array}{c}\text { R. solani } 618 \\
(\mathrm{AG} 4)\end{array}$ & & $\begin{array}{l}\text { R. solani } 509 \\
(\text { AG 2-1) }\end{array}$ & $\begin{array}{l}\text { R. solani } 618 \\
(\mathrm{AG} 4)\end{array}$ \\
\hline ThF2-12 & $89.60 \mathrm{a}$ & $77.38 \mathrm{~b}$ & T. $h 11^{1}$ & $98.48 \mathrm{a}$ & $89.82 \mathrm{a}$ \\
\hline ThF2-1 & $88.53 \mathrm{a}$ & $88.36 \mathrm{a}$ & ThF3-7 & $97.55 \mathrm{a}$ & $81.07 \mathrm{~b}$ \\
\hline ThF2-18 & $82.62 \mathrm{a}$ & $87.29 \mathrm{a}$ & ThF3-2 & $88.40 \mathrm{~b}$ & $85.60 \mathrm{ab}$ \\
\hline T. $h 291^{1}$ & $77.24 \mathrm{~b}$ & $75.24 \mathrm{~b}$ & ThF3-4 & $78.93 \mathrm{~b}$ & $88.27 \mathrm{ab}$ \\
\hline ThF2-10 & $65.38 \mathrm{c}$ & $75.11 \mathrm{~b}$ & ThF3-3 & $78.84 \mathrm{~b}$ & $91.73 \mathrm{a}$ \\
\hline T. $h \mathrm{~V}^{1}$ & $64.13 \mathrm{c}$ & $89.38 \mathrm{a}$ & ThF3-6 & $77.82 \mathrm{~b}$ & $53.29 \mathrm{c}$ \\
\hline & & & T. $h \mathrm{~V}^{1}$ & $64.13 \mathrm{c}$ & $89.38 \mathrm{a}$ \\
\hline $\begin{array}{l}\text { C. Strains from series } \\
\text { ThF4 ThV x Th12 }\end{array}$ & $\begin{array}{l}\text { R. solani } 509 \\
\text { (AG 2-1) }\end{array}$ & $\begin{array}{l}\text { R. solani } 618 \\
\text { (AG 4) }\end{array}$ & $\begin{array}{l}\text { D. Strains from series } \\
\text { ThF5 Th11 x Th12 }\end{array}$ & $\begin{array}{l}\text { R. solani } 509 \\
(\text { AG 2-1) }\end{array}$ & $\begin{array}{l}\text { R. solani } 618 \\
(\mathrm{AG} 4)\end{array}$ \\
\hline T. $h 12^{1}$ & $91.73 \mathrm{a}$ & $99.11 \mathrm{a}$ & ThF5-8 & $100.00 \mathrm{~b}$ & $96.40 \mathrm{~b}$ \\
\hline ThF4-13 & $91.64 \mathrm{a}$ & $97.07 \mathrm{a}$ & T. $h 11^{1}$ & $98.48 \mathrm{~b}$ & $89.82 \mathrm{c}$ \\
\hline ThF4-15 & $70.26 \mathrm{~b}$ & $83.78 \mathrm{~b}$ & T. $h 12^{1}$ & $91.73 \mathrm{a}$ & $99.11 \mathrm{a}$ \\
\hline T. $h \mathrm{~V}^{1}$ & $64.13 \mathrm{~b}$ & $89.38 \mathrm{~b}$ & & & \\
\hline E. Strains from series & R. solani 509 & R. solani 618 & & & \\
\hline ThF6 Th12 xTh291 & $(\mathrm{AG} \mathrm{2-1)}$ & $(\mathrm{AG} 4)$ & & & \\
\hline T. $h 12^{1}$ & $91.73 \mathrm{a}$ & $99.11 \mathrm{a}$ & & & \\
\hline ThF6-2 & $90.04 \mathrm{a}$ & $85.82 \mathrm{~b}$ & & & \\
\hline T. $h 291^{1}$ & $77.24 \mathrm{~b}$ & $75.24 \mathrm{c}$ & & & \\
\hline
\end{tabular}

${ }^{1}$ Parental strain. Different letters in columns and rows indicate significant differences after Tukey's test at $\mathrm{P} \leq 0.05$. 
Table 4. Effect of different mutants on canker level and mortality of tomato plants, cv. 92.95 (A) and Gondola (B), inoculated with $R$. solani 618 under glasshouse conditions.

\begin{tabular}{|c|c|c|c|c|c|c|c|}
\hline \multirow{2}{*}{$\begin{array}{l}\text { A. cv. } 92.95 \\
\text { Control }\end{array}$} & \multicolumn{2}{|c|}{ Canker level ${ }^{1.2}$} & \multirow{2}{*}{$\frac{\text { Mortality, \% }}{100}$} & \multirow{2}{*}{$\frac{\text { B. cv. Gondola }}{\text { Control }}$} & \multicolumn{2}{|c|}{ Canker level ${ }^{1.2}$} & \multirow{2}{*}{$\begin{array}{c}\text { Mortality, \% } \\
80\end{array}$} \\
\hline & 3 & $\mathrm{c}$ & & & 5 & e & \\
\hline Pencycuron & 2.8 & $\mathrm{bc}$ & 80 & Pencycuron & 3 & de & 80 \\
\hline Th12 $2^{3}$ & 1 & $\mathrm{ab}$ & 20 & Th12 $2^{3}$ & 2.7 & cde & 20 \\
\hline $\operatorname{Th} 291^{3}$ & 0.8 & $a b$ & 20 & $\operatorname{Th} 291^{3}$ & 1.5 & abcd & 10 \\
\hline $\mathrm{ThV}^{3}$ & 2.4 & $a b c$ & 10 & $\mathrm{ThV}^{3}$ & 1.8 & abcd & 10 \\
\hline Th1 $11^{3}$ & 2.3 & $a b c$ & 10 & Th1 $11^{3}$ & 2.5 & bcd & 20 \\
\hline ThF2-18 & 2 & $a b c$ & 0 & ThF2-18 & 1 & $a b c$ & 0 \\
\hline ThF3-3 & 1.8 & $a b c$ & 0 & ThF3-3 & 2.2 & abcd & 0 \\
\hline ThF4-15 & 1.2 & $a b c$ & 0 & ThF4-15 & 0.4 & a & 0 \\
\hline ThF2-1 & 0.6 & a & 0 & ThF2-1 & 1.8 & abcd & 0 \\
\hline ThF5-8 & 0.6 & $\mathrm{a}$ & 0 & ThF5-8 & 0.6 & $a b c$ & 0 \\
\hline
\end{tabular}

${ }^{1}$ Crown canker (size of area showing lesions in crown related to stem perimeter) was assessed using the following scale to establish the degree of the disease: $0: 0 \%$ area affected, healthy plant; $1:<1 \%$ area affected, slight disease; $2: 5-30 \%$ affected area, moderate disease; $3: 30-60 \%$ area affected, significant disease; $4: 60-90 \%$ area affected, severe disease; and 5: $>90 \%$ area affected, dead plant.

${ }^{2}$ Identical letters in columns indicate that no significant differences were found after analysis by ANOVA ( $95 \%$ confidence). ANOVA was followed by the Tukey's test only when significant differences were detected. Canker parameters were analyzed by the Kruskal-Wallis non-parametric test with pair comparison by the Mann-Whitney test ( $95 \%$ confidence).

${ }^{3}$ Parental strains.

Protoplast fusion, whether interspecific (Mohamed and Haggag, 2010) or intraspecific (Besoain et al., 2007; Fahmi et al., 2012), is universally applied as a useful tool for improving fungal strains. Nevertheless, as gene recombination occurs randomly, fusants can improve, maintain or lose the properties of their parental strains, which supports our findings and those of other groups.

The number of fusant Trichoderma strains that improved their inhibitory effect on the growth of $R$. solani 509 (AG-2-1) was always higher than those inhibiting $R$. solani 618 (AG-4). Controlling the AG-4 strains has been described as more difficult because of their pathogenesis and aggressiveness (Anderson, 1982; Sneh et al., 1991) as has been previously shown (Anderson, 1977). Thus, results from in vitro experiments could reflect this difficulty. Additionally, it is important to mention that most of the fusants were better inhibitors than at least one of their corresponding parents in dual cultures, which supports the goal of obtaining improved strains from wild ones (Rey et al., 2000). Similar results have been reported by Sivan and Harman (1991) for T. harzianum 1295-22, a product of protoplast fusion $(\mathrm{T} 12 \times \mathrm{T} 95)$ that was more effective for rhizosphere competition, by Besoain et al. (2007), who reported that several protoplast fusion strains improved their inhibitory effect on P. lycopersici and also showed a higher growth rates than their corresponding parents, and by Ahmed et al. (2007), who reported that several strains showed improved chitinase activity and reduced $R$. solani growth, among other pathogens tested, in vitro,.

The inhibitory activity of the Trichoderma strains tested in dual cultures on $R$. solani 509 and on $R$. solani 618 may be explained as competition for nutrients and space among other resources, without modifying $\mathrm{pH}$, according to results obtained in vitro by other authors (Howell, 2003; Benítez et al., 2004).

The inhibition of $R$. solani 509 and 618 growth due to volatile metabolites was negligible except for fusant ThF2-12 on R. solani 509 (Table 3), which suggests that, in the latter case, these types 
of compounds might be involved in the biocontrol of this pathogen. In opposition to our results are those of Küçük and Kivanç (2003), which showed that the Trichoderma T9 strain controlled the development of $R$. solani, or those of Besoain et al. (2007), in which a protoplast fusion product inhibited $P$. lycopersici development; volatile metabolites were involved in both cases. Nevertheless, it is important to consider that strain improvement by protoplast fusion could result in significant differences among the new strains as gene recombination could increase or decrease the secretion of volatile metabolites (Hanson, 2002).

On the other hand, most of the Trichoderma strains tested in this work caused growth inhibition of more than $80 \%$ in $R$. solani 509 and $R$. solani 618 through diffusible metabolites (Table 3), which is supported by previous reports (Küçük and Kivanç, 2003) of some T. harzianum isolates completely inhibiting $R$. solani development. The high degree of growth inhibition of $R$. solani 509 and $R$. solani 618 by all of the strains (Table 3 ) suggests that the inhibitory effect observed in dual cultures (Table 1) could mostly be attributed to diffusible metabolites. These are low molecular weight antibiotics (Benítez et al., 2004) that, in combination with hydrolytic enzymes, result in antagonistic levels (Rey et al., 2000) higher than could be reached separately. Moreover, low molecular weight enzymes could diffuse through dialysis membranes in the same way as antibiotics and thus produce inhibitory effects higher than those observed in dual cultures.

The effect of diffusible metabolites on pathogen development has been reported by several authors. In fact, Howell (2003) established that the biocontrol of Pythium spp. by T. harzianum T-12 and $T$. koningii $\mathrm{T}-8$ was not due to mycoparasitism but to toxic metabolites that inhibited the pathogen's growth. In addition, the author also established that a $T$. virens mutant (deficient in mycoparasitism and in gliotoxin synthesis) was as efficient as the parental strain (G-6) in the control of $P$. ultimum and $R$. solani. The use of fungal culture filtrates as an alternative for testing the effect of diffusible metabolites from inter-specific protoplast mutants has also been reported (Mohamed and Haggag, 2010), and the results support the inhibition of pathogen growth by these types of metabolites.

A comparison of the results from the dual cultures and diffusible metabolites experiments (Tables 1 and 3) allowed us to see a higher biocontrol effect on $R$. solani 509 (AG 2-1) than on $R$. solani 618 (AG-4) by most of the Trichoderma strains tested in dual cultures (Table 1). These results were not observed in the strongest biocontrol results for diffusible metabolites (Table 3) where no significant differences were observed between the growth inhibition of $R$. solani 509 and 618 for most of the fusant strains. Therefore, and based in the diffusible metabolites results, ThF2-1, ThF218, ThF3-3, ThF4-15 and ThF5-8 were selected to develop the glasshouse, $R$. solani 618 control experiments. The pathogen was chosen because of its importance in terms of pathogenesis, aggressiveness, and number of target plant species (Anderson, 1982; Sneh et al., 1991), and the two tomato cvs., 92.95 and Gondola, differ in their susceptibility to the pathogen.

Two of the selected fusants, ThF2-1 (ThV×Th291) and ThF5-8 (Th11 $\times$ Th12), were able to significantly reduce the damage produced by $R$. solani 618 in both tomato cvs. It is obvious that the susceptibility of the plant to the pathogen has no relation to the activity of the biocontrol agent. In addition, the fact that two of the five selected fusants were able to control $R$. solani 618 agrees with results obtained by Fahmi et al. (2012), who tested for the ability of protoplast fusion mutants of $T$. harzianum strains tolerant to fungicides to reduce tomato damping-off in greenhouse assays. They showed that only one of the seven selected mutants, which showed improved biocontrol activity in vitro compared to their parental strains, was capable of reducing the disease in plants. Additionally, the chemical treatment of $T$. harzianum resulted in few mutants with improved ability to control 
the stem blight of soybean in glasshouse assays (Singh and Upadhyay, 2009) or tomato crown canker (Montealegre et al., 2010). Thus, methods involving random gene recombination, such as protoplast fusion or unspecific gene alteration as occurs in chemical mutation, will result in a high number of mutants, of which only a few will show improved biocontrol characteristics in in vitro experiments and even fewer in glasshouse experiments when compared to their parental strains.

Mortality suppression by all the fusants tested in the two tomato cvs. did not correlate with their ability to reduce canker level, which suggests that the suppression of plant mortality is not necessarily associated with biocontrol. Further studies will be necessary to elucidate this point.
In summary, several fusant Trichoderma strains obtained through protoplast fusion improved the biocontrol ability of at least one of the wild T. harzianum parents in the in vitro experiments. However, only some fusants repeated this behavior once the assays were run in glasshouse conditions. Thus, specific characteristics of the fusants would most likely be interacting with $R$. solani and/or with a specific tomato cv., a fact that must be taken into account before recommending a general use of a $\mathrm{BCM}$.

\section{Acknowledgements}

This work was funded by FONDECYT (Fondo Nacional de Desarrollo Científico y Tecnológico) (Project 1040531-04), Santiago, Chile.

\title{
Resumen
}

\begin{abstract}
J.R. Montealegre, F. Ochoa, X. Besoain, R. Herrera y L.M. Pérez. 2014. Biocontrol de Rhizoctonia solani in vivo y en invernadero, con cepas mejoradas de Trichoderma spp. Cien. Inv. Agr. 41(2):197-206. Se comparó la capacidad de cepas de Trichoderma spp., obtenidas previamente por fusión de protoplastos, con la de sus correspondientes cepas parentales, para biocontrolar a Rhizoctonia solani. El efecto biocontrolador se analizó sobre dos cepas de $R$. solani: 509 (GA 2-1) y 618 (GA 4). Las cepas producto de fusión de protoplastos de Trichoderma spp. fueron más efectivas que al menos una de las correspondientes cepas parentales. La inhibición más alta en experimentos de cultivos duales, se observó con las cepas ThF2-1 (89,79\%), ThF3-3 (90,55\%), ThF4-15 (91,75\%) y ThF5-8 (77,67\%) sobre $R$. solani 509; mientras que el efecto biocontrolador sobre $R$. solani 618 , sólo logró un $60,19 \%$ de inhibición con la cepa ThF2-1. El efecto inhibidor del desarrollo se debió principalmente a la secreción de metabolitos difusibles. El porcentaje de mortalidad y nivel de cancro en plantas de tomate se evaluó en experimentos de invernadero, en los que todas las cepas producto de la fusión de protoplastos de Trichoderma spp. suprimieron la mortalidad de plantas de tomate, y solamente ThF2-1 y ThF5-8 disminuyeron significativamente el nivel de cancro.
\end{abstract}

Palabras clave: Bromuro de metilo, control biológico, Solanum lycopersicum, tomate.

\section{References}

Ahmed, M., A.M. El-Bondkly, and F.N. Talkhan. 2007. Intra-strain crossing in Trichoderma harzianum via protoplast fusion to enhance chitinase productivity and biocontrol activity. Arab Journal of Biotechnology 102:233-240.

Anderson, N.A. 1977. Evaluation of the Rhizoctonia complex in relation to seedling blight of flax. Plant Disease Reporter 61: 140-142.
Anderson, N.A. 1982. The genetics and pathology of Rhizoctonia solani. Annual Review of Phytopathology 20:329-347.

Benítez, T., A.M. Rincón, M.C.Limón, and A.C. Codón. 2004. Biocontrol mechanisms of Trichoderma strains. International Microbiology 7:249260.

Besoain, X., L.M. Pérez, A. Araya, L1. Lefever, M. Sanguinetti, and J.R. Montealegre. 2007. New strains obtained after UV treatment and proto- 
plast fusion of native Trichoderma harzianum: their biocontrol activity on Pyrenochaeta lycopersici. Electronic Journal of Biotechnology 104:604-617.

Dennis, C., and J. Webster. 1971a. Antagonistic properties of species-groups of Trichoderma III. Hyphal interaction. Transactions of the British Mycological Society 57:363-369.

Dennis, C., and J. Webster. 1971b. Antagonistic properties of species-groups of Trichoderma II. Production of volatile antibiotics. Transactions of the British Mycological Society 57:41-48.

Fahmi, A.I., A.D. Al-Talhi, and M.M. Hassan. 2012. Protoplast fusion enhances antagonistic activity in Trichoderma sp. Nature and Science 105:100-106.

Hanson, L. 2002. Biocontrol efficacy and other characteristics of protoplast fusants between Trichoderma koningii and T. virens. Mycology Resource 1063:321-328.

Howell, C. 2003. Mechanisms employed by Trichoderma species in the biological control of plant diseases: The history and evolution of current concepts. Plant Disease 87:4-10.

Küçük, Ç., and M. Kivanç. 2003. Isolation of Trichoderma spp. and determination of their antifungal, biochemical and physiological features. Turkish Journal of Biology 27:247-253.

Latorre, B. 2004. Enfermedades de las plantas cultivadas. Ediciones Universidad Católica de Chile, Santiago, Chile. 638 pp.

Mohamed, H.A.A., and W.M. Haggag. 2010. Mutagenesis and inter-specific protoplast fusion between Trichoderma koningii and Trichoderma reesei for biocontrol improvement. American Journal of Scientific and Industrial Research 13:504-515.

Montealegre, J., and C. Larenas. 1995. Use of Trichoderma harzianum as biological control of Sclerotium rolfsii in beans. Fitopatología 303:160-166.

Montealegre, J., R. Reyes, X. Besoain, L.M. Pérez, and R. Herrera. 2003. Identificación de grupos de anastomosis de cepas de Rhizoctonia solani Kühn aisladas de tomates en la Quinta Región de Chile. Boletín Micológico 18:47-51.
Montealegre, J.R., L. Valderrama, S. Sánchez, R. Herrera, X. Besoain, and L.M. Pérez. 2010. Biological control of Rhizoctonia solani in tomatoes with Trichoderma harzianum mutants. Electronic Journal of Biotechnology 13:1-11.

Ogawa, K., N. Yoshida, W. Gesnara, C.A. Omumasaba, and C.H. Chamuswarng. 2000. Hybridization and breeding of the benomyl resistant mutant, Trichoderma harzianum antagonized to phytopathogenic fungi by protoplast fusion. Bioscience, Biotechnology and Biochemistry 644:833-836.

Prabavathy, V.R., N. Mathivanan, E. Sagadevan, K. Murugesan, and D. Lalithakumari. 2006. Self-fusion of protoplasts enhances chitinase production and biocontrol activity in Trichoderma harzianum. Bioresource Technology 9718:2330-2334.

Rey, M., J. Delgado-Jarana, A.M. Rincón, M.C. Limón, and T. Benítez. 2000. Mejora de cepas de Trichoderma para su empleo como biofungicidas. Revista Iberoamericana de Micología 17:31-36.

Santander, C., J. Montealegre, and R. Herrera. 2003. Control biológico de Rhizoctonia solani en tomate en suelos previamente sometidos a solarización y bromuro de metilo. Ciencia e Investigación Agraria 302:107-112.

Singh, B. K., and R.S. Upadhyay. 2009. Management of southern stem blight of soybean by PCNB resistant mutants of Trichoderma harzianum 4572 incited by Sclerotium rolfsii. Journal of Agricultural Technology 51:85-98.

Sivan, A., and G. Harman. 1991. Improved rhizosphere competence in a protoplast fusion progeny of Trichoderma harzianum. Journal Microbiology 1371:23-29.

Sneh, B., L. Burpee, and A. Ogoshi. 1991. Identification of Rhizoctonia species. APS Press, St. Paul, Minnesota, USA. 594 pp.

Stasz, T.E., G.E. Harman, and N.F. Weeden. 1988. Protoplast preparation and fusion in two biocontrol strains of Trichoderma harzianum. Mycologia 80:141-150. 